\title{
Efek Pemberian Niasin terhadap Glukosa Darah pada Tikus Wistar dengan Obesitas
}

\author{
Robby Hermawan, Trully D. Sitorus, Herri S. Sastramihardja \\ Departemen Farmakologi Fakultas Kedokteran Universitas Padjadjaran-Rumah Sakit Hasan Sadikin
}

\begin{abstract}
Abstrak
Niasin memiliki kontroversi mengenai efeknya terhadap pengaturan glukosa darah. Penelitian bertujuan untuk mengetahui efek niasin terhadap kadar glukosa darah pada tikus Wistar dengan obesitas yang diinduksi diet. Penelitian ini merupakan penelitian eksperimental laboratorik dengan desain paralel yang menggunakan randomisasi di laboratorium Farmakologi Fakultas Kedokteran Unpad periode Juli 2008-Maret 2009. Penelitian dilakukan pada tikus jantan galur Wistar. Pertama, semua subjek penelitian diinduksi menjadi obesitas dengan diet tinggi lemak selama 10 minggu. Tikus yang memenuhi kriteria dibagi dalam dua kelompok secara acak. Kelompok pertama diberikan plasebo. Kelompok kedua diberikan niasin. Niasin dan plasebo diberikan selama 20 hari. Dosis niasin yang diberikan sebesar $0,135 \mathrm{mg} / \mathrm{gBB} /$ hari. Glukosa darah puasa (GDP) dan tes toleransi glukosa oral (TTGO) diukur pada hari ke-21. Hasil penelitian menunjukkan bahwa tidak terdapat perbedaan yang bermakna antara kelompok kontrol dan perlakuan baik pada GDP maupun TTGO. GDP kelompok niasin lebih rendah 4,0 mg/dL (IK95\% -0,342-8,4) dibandingkan dengan kelompok kontrol, dengan p=0,068, sedangkan hasil TTGO kelompok niasin lebih tinggi 0,8 mg/dL (IK95\% -5,6-7,1) dibandingkan dengan kelompok kontrol, dengan $\mathrm{p}=0,800$. Disimpulkan pemberian niasin tidak menyebabkan perbedaan kadar GDP dan TTGO pada tikus jantan galur Wistar dengan obesitas yang diinduksi diet. [MKB. 2011;43(1):16-20].
\end{abstract}

Kata kunci: Glukosa darah puasa, niasin, obesitas, tes toleransi glukosa oral

\section{The Effect of Niacin to the Blood Glucose in Obese Wistar Rats}

\begin{abstract}
Niacin has many controversies about its effect to the management of the blood glucose. The objective of the research was to know the effect of niacin to the blood glucose in obese wistar rats. This research was an experimental laboratory study with a parallel design using randomization. Male Wistar rats were used in this research. All rats were induced to be obesed with high-fat feeding for 10 weeks. Rats that fulfill the criteria were randomly divided into two groups. The first group was given the placebo. The second group was given the niacin. The niacin and the placebo were given for the next 20 days. The niacin dose was $0.135 \mathrm{mg} / \mathrm{g}$ body weight/day. Fasting blood glucose (FBG) and oral glucose tolerance test (OGTT) were taken on the 21 st day. The results showed that there were not any significant differences in FBG and OGTT between control and treated group. The FBG of the niacin group was $4.0 \mathrm{mg} / \mathrm{dL}(95 \% \mathrm{CI}-0.342-8.4)$ lower than the control group, with $\mathrm{p}=0.068$. The OGTT result of the niacin group was $0.8 \mathrm{mg} / \mathrm{dL}(95 \% \mathrm{CI}-5.6-7.1)$ higher than the control group, with $\mathrm{p}=0.800$. This study concludes that taking niacin does not cause differences in FBG and OGTT results in the male Wistar rats with diet induced obesity. [MKB. 2011;43(1):16-20].
\end{abstract}

Key words: Fasting blood glucose, niacin, obesity, oral glucose tolerance test

Korespondensi: Robby Hermawan, dr., M.Kes, Departemen Farmakologi Fakultas Kedokteran Universitas PadjadjaranRumah Sakit Hasan Sadikin, jalan Pada Asih 4 Bandung, mobile 08122123839,e-mail antrobher@yahoo.com 


\section{Pendahuluan}

Niasin telah digunakan sebagai salah satu obat dislipidemia sejak tahun 1950, tetapi oleh karena sering terjadi efek samping flushing maka jarang digunakan. ${ }^{1}$ Niasin banyak digunakan kembali pada beberapa tahun terakhir. Hal ini disebabkan penemuan sediaan yang dapat mengatasi efek samping flushing, yaitu sediaan extendedrelease. ${ }^{2}$ Niasin juga direkomendasikan sebagai obat dislipidemia karena memiliki beberapa kelebihan dibandingkan dengan obat dislipidemia lain, terutama mencegah aterosklerosis. ${ }^{3}$ Niasin merupakan obat yang memperbaiki hampir semua profil lipid. ${ }^{3}$ Niasin menurunkan kadar kolesterol total, low-density lipoproteins cholesterol (LDL-C) dan trigliserida serum. ${ }^{2}$ Efek peningkatan kadar high-density lipoproteins cholesterol (HDL-C) pada serum oleh niasin merupakan yang terbesar di antara obat dislipidemia. ${ }^{4}$ Niasin merupakan satu-satunya obat yang dapat menurunkan kadar lipoprotein (a) secara bermakna., ${ }^{2,5}$ Niasin dapat mengubah small-LDL menjadi large-LDL yang bersifat kurang aterogenik. ${ }^{6}$ Niasin meningkatkan produksi tissue plasminogen activator (tPA) dan menurunkan kadar fibrinogen serum sehingga dapat mencegah kejadian trombosis. Niasin merupakan obat kombinasi yang baik jika digabungkan dengan obat golongan statin oleh karena keduanya akan saling melengkapi dalam memperbaiki dislipidemia aterogenik. ${ }^{2}$

Hal yang dipaparkan di atas menyebabkan niasin kembali menjadi obat dislipidemia yang banyak digunakan, tetapi penggunaan niasin masih memiliki hambatan. Salah satu hambatan adalah perbedaan pendapat mengenai pengaruh niasin pada pengaturan kadar glukosa darah. Perbedaan juga mengakibatkan dualisme pada rekomendasi penggunaan niasin untuk penderita dislipidemia yang disertai faktor risiko resistensi insulin.

Beberapa penelitian menyatakan pemberian niasin menyebabkan gangguan toleransi glukosa dan peningkatan gula darah puasa (GDP), ${ }^{7-11}$ tetapi keadaan ini tidak terdapat pada penelitian lain. ${ }^{12-15}$

Perbedaan pendapat tersebut menarik untuk ditelaah lebih lanjut. Perbedaan pendapat dapat diakibatkan oleh perbedaan karakteristik subjek masing-masing penelitian, oleh karena itu kesimpulan mengenai keamanan pemberian niasin dalam hal pengaturan glukosa darah harus dibuat dengan mempertimbangkan karakteristik subjek penelitian. Penelitian mengenai efek niasin terhadap gangguan toleransi glukosa dan GDP yang dilakukan pada manusia terdiri atas bermacam subjek penelitian. Ada penelitian yang menggunakan subjek orang normal, ${ }^{12}$ tetapi ada juga yang membatasi penderita dislipidemia tanpa diabetes melitus, ${ }^{7,9}$ diabetes melitus tipe $2^{8,11,15}$ dan tipe $1,{ }^{13}$ hipertrigliseridemia dengan berat badan stabil, ${ }^{10}$ atau penderita penyakit arteri perifer, ${ }^{14}$ tetapi penelitian khusus pada subjek penelitian yang menderita obesitas belum ada.

Obesitas memiliki prevalensi yang tinggi dan semakin meningkat. Hal ini dapat dilihat pada data dari National Health and Nutrition Examination Survey (NHANES). Penduduk Amerika dengan obesitas (body mass index/BMI >30) telah meningkat dari level 14,5\% (tahun 1976-1980) menjadi 30,5\% (tahun 1999-2000). ${ }^{16}$ Obesitas merupakan penyakit yang sering disertai dengan dislipidemia. Profil dislipidemia pada penderita obesitas secara umum ditandai dengan kadar trigliserida yang tinggi dan kadar kolesterol HDL serum yang rendah. Profil dislipidemia tersebut sesuai dengan indikasi pemberian niasin, akan tetapi dengan diberikannya niasin pada obesitas akan menimbulkan permasalahan karena obesitas menyebabkan resistensi insulin, sedangkan keamanan pemberian niasin dalam hal pengaturan glukosa darah juga belum jelas. Keadaan tersebut menyebabkan keamanan pemberian niasin pada penderita obesitas patut dipertanyakan. ${ }^{16}$

Hewan coba dipilih agar subjek penelitian lebih homogen dan lebih mudah untuk menyeragamkan dosis serta lama pemberian niasin. Faktor pengganggu yang terdapat pada penelitian manusia juga dapat diminimalisasi, seperti konsumsi obat-obatan lain misalnya obat hiperglikemia oral, insulin, obat hipertensi, dan obat dislipidemia lain. Pengaruh diet dan olahraga yang mempengaruhi toleransi glukosa dan GDP pada manusia juga dapat diminimalisasi dengan penelitian pada hewan coba.

Penelitian ini bertujuan untuk mengetahui efek pemberian niasin terhadap kadar glukosa darah (puasa dan hasil tes toleransi glukosa oral) pada tikus jantan galur Wistar dengan obesitas yang diinduksi diet.

\section{Metode}

Penelitian pada tikus jantan galur Wistar ini merupakan penelitian eksperimental laboratorik, desain paralel dengan randomisasi. Semua subjek penelitian diinduksi menjadi obesitas dengan diet tinggi lemak ad libitum selama sepuluh minggu. Obesitas tikus ditentukan berdasarkan indeks obesitas Lee. ${ }^{17}$ Tikus dinyatakan obes jika nilai indeks obesitas Lee $>0,3$. Indeks obesitas Lee dihitung dengan rumus: Indeks Obesitas Lee $=\frac{\sqrt{\text { Berat Badan (gram) x 10 }}}{\text { Panjang Nasoanal }(\mathrm{mm})}$

Tikus yang memenuhi kriteria obesitas dibagi 
dalam 2 (dua) kelompok secara acak. Kelompok pertama merupakan kelompok kontrol, yaitu kelompok yang diberikan plasebo. Kelompok kedua merupakan kelompok perlakuan, yaitu kelompok yang diberikan niasin. Niasin dan plasebo diberikan selama 20 hari. Dosis niasin yang diberikan sebesar $0,135 \mathrm{mg} / \mathrm{gBB} /$ hari, dosis yang ekivalen dengan 1,5 g/hari pada manusia dewasa. Gula darah puasa dan TTGO diukur pada hari ke-21 untuk menilai efek terhadap pengaturan glukosa darah. Gula darah puasa diperiksa dengan mengukur kadar glukosa darah setelah tikus dipuasakan 5 jam. Tes toleransi glukosa oral dilakukan dengan pemeriksaan kadar glukosa darah 2 jam setelah pemberian larutan dekstrosa $40 \%$ dengan dosis $1 \mathrm{~g} / \mathrm{kgBB}$ per oral pada tikus yang sudah puasa 5 jam.

Penentuan besar sampel minimal berdasarkan perhitungan statistik dengan menetapkan taraf kepercayaan sebesar $95 \%$ dan power test $95 \%$ menghasilkan minimal 8 (delapan) sampel untuk tiap kelompok penelitian. Analisis data GDP dan hasil TTGO dilakukan dengan menggunakan uji t tidak berpasangan.

Analisis statistik menggunakan program SPSS for Windows versi 16.0

Penelitian ini dilaksanakan di laboratorium Farmakologi Fakultas Kedokteran Universitas Padjadjaran-Rumah Sakit Hasan Sadikin Bandung periode Juli 2008-Maret 2009.

\section{Hasil}

Jumlah sampel yang didapatkan adalah 18 tikus dengan 10 tikus kelompok kontrol dan 8 tikus kelompok perlakuan. Karakteristik dasar subjek penelitian dapat dilihat pada Tabel 1. Data tersebut diperoleh sebelum masa perlakuan, tetapi setelah pemberian diet tinggi lemak selama 10 minggu. Gula darah puasa dan TTGO tidak menunjukkan perbedaan yang bermakna antara kedua kelompok sebelum perlakuan.
Gula darah puasa kelompok kontrol dan niasin setelah masa perlakuan dapat dilihat pada Gambar 1. Pada kelompok niasin GDP rata-rata adalah 67,9 (SD 4,49) mg/dL, sedangkan pada kontrol 71,9 (SD 4,23) mg/dL. Uji normalitas data GDP kedua kelompok menggunakan uji KolmogorovSmirnov menunjukkan distribusi normal. Varians data kedua kelompok tidak memiliki perbedaan yang bermakna setelah diuji dengan Levene's test for equality of variances, oleh karena itu dipergunakan uji t tidak berpasangan. Perbedaan GDP antara kedua kelompok sebesar 4,0 mg/ dL (IK95\% -0,342-8,4) dengan $p=0,068$, berarti tidak terdapat perbedaan bermakna GDP antara kedua kelompok.

Hasil TTGO kelompok kontrol dan niasin setelah masa perlakuan dapat dilihat pada Gambar 2. Hasil TTGO rata-rata kelompok niasin adalah 80,4 (SD 5,80) mg/dL, sedangkan hasil TTGO kelompok kontrol adalah 79,6 (SD 6,72) mg/ dL. Uji normalitas data TTGO kedua kelompok dengan uji Kolmogorov-Smirnov menunjukkan distribusi normal. Varians data kedua kelompok tidak memiliki perbedaan yang bermakna setelah diuji dengan Levene's test for equality of variances. Oleh karena itu digunakan uji t tidak berpasangan. Terdapat perbedaan hasil TTGO $0,8 \mathrm{mg} / \mathrm{dL}$ (IK95\% -5,6-7,1) dengan $\mathrm{p}=0,800$. Hal ini menunjukkan tidak terdapat perbedaan bermakna hasil TTGO kelompok kontrol dengan kelompok niasin.

\section{Pembahasan}

Berdasarkan karakteristik subjek menunjukkan bahwa randomisasi yang dilakukan sebelum masa perlakuan telah berhasil membagi kedua kelompok setara berdasarkan variabel GDP, TTGO, berat badan, panjang badan, dan indeks obesitas Lee.

Uji t tidak berpasangan data GDP kelompok kontrol dan kelompok perlakuan tidak ada

Tabel 1 Karakteristik Dasar Subjek Penelitian

\begin{tabular}{lccc}
\hline Karakteristik & Kelompok Kontrol & Kelompok Perlakuan & Nilai p* \\
\hline Jumlah Subjek & 10 & 8 & - \\
BB rata-rata (g) & 291,4 (SD 37,30) & 294,2 (SD 72,19) & - \\
PB rata-rata (cm) & 20,86 (SD 0,704) & 20,61 (SD 1,221) & - \\
IOL rata-rata & 0,319 (SD 0,0057) & 0,321 (SD 0,0136) & 0,950 \\
GDP rata-rata (mg/dL) & 70,7 (SD 8,34) & 70,5 (SD 3,50) & 0,580 \\
TTGO rata-rata (mg/dL) & 78,1 (SD 8,27) & 75,5 (SD 11,29) & \\
Keterangan : BB, berat badan; PB, panjang badan; IOL, Indeks Obesitas Lee; GDP, glukosa darah puasa; TTGO, \\
* : berdasarkan uji t tidak berpasangan
\end{tabular}




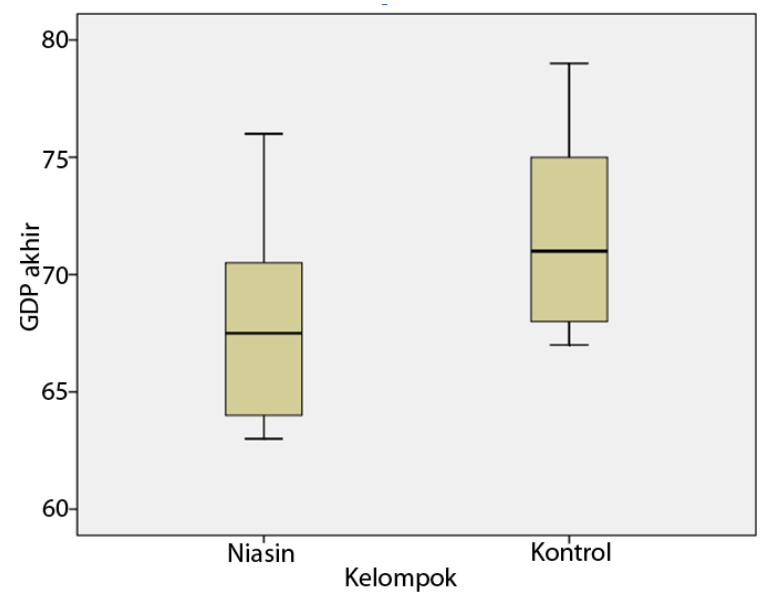

Gambar 1 GDP setelah Masa Perlakuan

perbedaan yang bermakna $(\mathrm{p}>0,05)$. Uji t tidak berpasangan data TTGO kelompok kontrol dan kelompok perlakuan juga tidak ada perbedaan bermakna $(p>0,05)$. Hal ini membuktikan bahwa pemberian niasin pada tikus jantan yang telah dilakukan induksi dietnya, tidak menyebabkan perbedaan kadar GDP atau hasil TTGO jika dibandingkan dengan kelompok kontrol.

Resistensi insulin di hati dapat meningkatkan GDP, sedangkan resistensi insulin di otot dan jaringan adiposa meningkatkan TTGO. Niasin dan obesitas meningkatkan resistensi insulin,, 18 sehingga pemberian niasin pada obesitas dikhawatirkan dapat menyebabkan resistensi insulin yang dapat meningkatkan GDP dan hasil TTGO. Akan tetapi resistensi insulin bersifat relatif sehingga pada sel beta pankreas yang berfungsi normal, sekresi insulin akan ditingkatkan yang dapat mencegah peningkatan GDP. ${ }^{18}$ Dengan demikian normal tidaknya sel beta pankreas memegang peranan penting, sehingga diharapkan memiliki sel beta pankreas yang normal. Hal ini menyebabkan tidak terjadi peningkatan baik pada GDP maupun TTGO pada kelompok tikus yang diberi niasin karena sel beta pankreas yang normal tersebut dapat mengompensasi resistensi insulin dengan meningkatkan sekresinya. Kelemahan penelitian ini adalah tidak dilakukan pengukuran kadar insulin yang dapat memperkuat kesimpulan di atas.

Jika subjek yang mendapat niasin memiliki defek pada sel beta pankreas yang menyebabkan respons insulin inadekuat, maka akan terdapat penurunan fungsi sel tersebut, karena adanya fenomena glukolipotoksisitas. ${ }^{19}$ Kadar glukosa dan kadar asam lemak bebas yang meningkat dapat merusak sel beta pankreas, tetapi jika hanya salah satu yang meningkat, tidak akan menyebabkan kerusakan. Niasin terbukti dapat meningkatkan

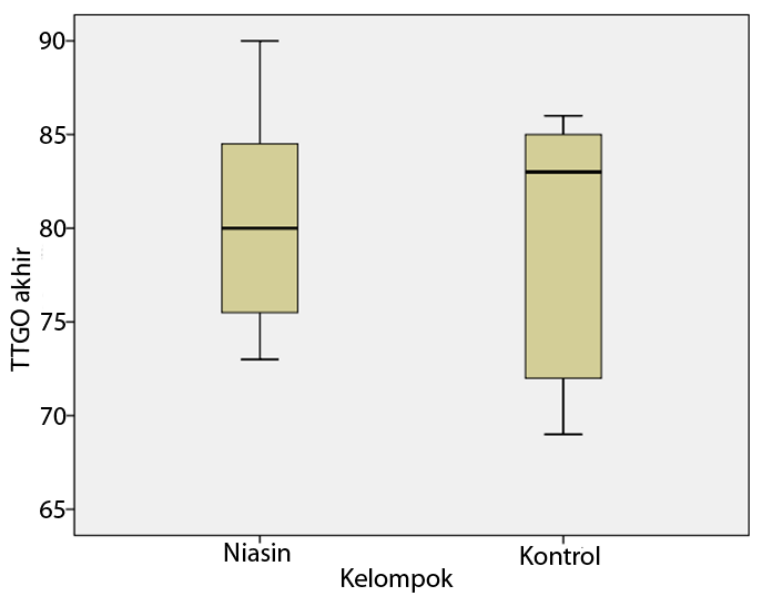

Gambar 2 TTGO setelah Masa Perlakuan

kadar asam lemak bebas, ${ }^{12}$ maka kemampuan sel beta pankreas untuk memproduksi insulin penting untuk mencegah peningkatan glukosa darah. Kegagalan pengaturan glukosa darah akan meningkatan kadar glukosa darah bersamaan dengan asam lemak bebas sehingga terjadi fenomena glukolipotoksisitas.

Hal lain yang patut diperhatikan adalah fungsi sel beta pankreas yang menurun seiring dengan penambahan usia. ${ }^{20}$ Fungsi sel beta pankreas yang menurun karena usia akan mempengaruhi efek niasin pada pengaturan glukosa darah, juga melalui mekanisme glukolipotoksisitas yang sudah dijelaskan sebelumnya. Disimpulkan pemberian niasin tidak menyebabkan perbedaan kadar GDP dan TTGO pada tikus jantan galur Wistar dengan obesitas yang diinduksi diet.

\section{Daftar Pustaka}

1. Tenenbaum A, Fisman EZ, Motro M, Adler Y. Atherogenic dyslipidemia in metabolic syndrome and type 2 diabetes: therapeutic options beyond statins. Cardiovas Diabetol. 2006;5:20.

2. National Institutes of Health-National Heart, Lung, and Blood Institute. Executive summary of the third report of the national cholesterol education program (NCEP): expert panel on detection, evaluation, and treatment of high blood cholesterol in adults (Adult Treatment Panel III) final report. Circulation. 2002;106(25):3140-1.

3. McKenney J. New perspectives on the use of niacin in the treatment of lipid disorders. Arch Intern Med. 2004;164:697-705.

4. Vega GL, Grundy SM. Lipoprotein responses to treatment with lovastatin, gemfibrozil, and 
nicotinic acid in normolipidemic patients with hypoalphalipoproteinemia. Arch Intern Med. 1994;154:73-82.

5. Carlson LA, Hamsten A, Asplund A. Pronounced lowering of serum levels of lipoprotein $L p(a)$ in hyperlipidaemic subjects treated with nicotinic acid. J Intern Med. 1989;226:271-6.

6. Superko HR, Krauss RM. Differential effects of nicotinic acid in subjects with different LDL subclass patterns. Atherosclerosis. 1992;95:69-76.

7. Christensen NA, Achor RWP, Berge KG, Mason HL. Hypercholesteremia: effects of treatment with nicotinic acid for three to seven years. Chest. 1964;46:411-6.

8. Garg A, Grundy SM. Nicotinic acid as therapy for dyslipidemia in non-insulin dependent diabetes mellitus. JAMA. 1990;264(6):7236.

9. Tornvall P, Walldius G. A comparison between nicotinic acid and acipimox in hypertriglyceri-daemia: effects on serum lipids, lipoproteins, glucose tolerance and tolerability. J Intern Med. 1991;230(5):41521.

10. Wahlberg G, Walldius G, Efendic S. Effects of nicotinic acid on glucose tolerance and glucose incorporation into adipose in hypertriglyceridae-mia. Scand J Clin Lab Invest. 1992;52(6):537-45.

11. Rindone JP, Achacoso S. Effect of low-dose niacin on glucose control in patients with non-insulin dependent diabetes mellitus and hyperlipidemia. Am J Ther. 1996;3(9):637-9.

12. Alvarsson M, Grill V. Impact of nicotinic acid treatment on insulin secretion and insulin sensitivity in low and high insulin responders. Scand J Clin Lab Invest. 1996;56(6):563-70.

13. Gardner SF, Marx MA, White LM, Granberry MC, Skelton DR, Fonseca VA. Combination of low-dose niacin and pravastatin improves the lipid profile in diabetic patients without compromising glycemic control. Ann Pharmacother. 1997;31(6):677-82.

14. Elam MB, Hunninghake DB, Davis KB. Effect of niacin on lipid and lipoprotein levels and glycemic control in patient with diabetes and peripheral arterial disease: the ADMIT study: a randomized trial. JAMA. 2000;284(10):1263-70.

15. Grundy SM, Vega GL, McGovern ME, Tulloch BR, Kendall DM, Fitz-Patrick D, dkk. Efficacy, safety, and tolerability of oncedaily niacin for the treatment of dyslipidemia associated with type 2 diabetes. Arch Intern Med. 2002;162:1568-76.

16. Flier JS, Flier EM. Biology of obesity. Dalam: Fauci AS, Kasper DL, Longo DL, Braunwald E, Hauser SL, Jameson JL, dkk., penyunting. Harrison's principles of internal medicine. Edisi ke-17. New York: McGraw Hill; 2008. hlm. 462-7.

17. Campos KE, Volpato GT, Calderon IMP, Rudge MVC, Damasceno DC. Effect of obesity on rat reproduction and on the development of their adult offspring. Braz J Med Biol Res. 2008;41(2):122-5.

18. McCulloch DK, Kahn SE, Schwartz MW, Koerker DJ, Palmer JP. Effect of nicotinic acid-induced insulin resistance on pancreatic $\mathrm{B}$ cell function in normal and streptozocintreated baboons. J Clin Invest. 1991;87:1395401.

19. Poitout V, Robertson RP. Minireview: secondary beta-cell failure in type 2 diabetes-a convergence of glucotoxicity and lipotoxicity. Endocrinology. 2002;143:33942.

20. Chang AM, Smith MJ, Galecki AT, Bloem CJ, Halter JB. Impaired beta-cell function in human aging: response to nicotinic acidinduced insulin resistance. J Clin Endocrinol Metab. 2006;91(9):3303-9. 